\title{
Information Transparency of the Statement of Comprehensive Income: The Reporting Practice of WIG30 and DAX Companies
}

\author{
Jacek Gad
}

\begin{abstract}
This article aims to identify changes in the form of the statement of comprehensive income in companies in the WIG3O and DAX indices. It also aims to identify and grade components of other comprehensive income, in terms of the information transparency of the presentation options. The article demonstrates also the impact of national cultural dimensions on the form of the statement of comprehensive income. The study found that most of the surveyed companies present their statement of comprehensive income in two statements, with the number of accounting notes regarding comprehensive income presented by companies in their financial statements increasing over the period under study. The study identified four options for the presentation of other comprehensive income components used by the surveyed companies in the years 2012-2014, with the particular option chosen reflecting the different information transparency of the statement of comprehensive income. The results show that the practice of reporting in the area of the statement of comprehensive income of the DAX index companies is ahead of that in the WIG30 index. The research results on information transparency of the statement of comprehensive income correspond to one of the national cultural dimensions.
\end{abstract}

Keywords: financial statements, comprehensive income, WIG30, DAX, information transparency.

\section{INTRODUCTION}

Contemporary changes in economic reality are accompanied by changes in the tools with which companies communicate with the environment, including changes in the financial statements. Year on year, the financial statements of public companies are getting longer, and their form is also evolving. Globalization, the expanding scope of services provided, the

1 Jacek Gad, Ph.D., Department of Accounting, Faculty of Management, University of Lodz, ul. Matejki 22/26 St., 90-237 Łódż, Poland, e-mail: jgad@uni.lodz.pl. 
increasingly widespread use of financial instruments, and the constantly increasing information requirements resulting from IFRS, result in new areas which require more detailed information in the financial statements. The key question seems to be whether the increased scope and change in form of presenting information in the financial statements streamlines the communication process or causes misinformation.

In Europe, comprehensive income is a relatively new concept, and it appears that the problem of misinformation among users of financial statements may be caused by new concepts of reporting. Given the lack of European experience in the area of presenting components of other comprehensive income, it seems that research in this area is justified. Importantly, other comprehensive income provides an excellent platform for international comparative research. Regardless of the sector in which companies operate or location within the European Union capital market on which they are listed, the components of other comprehensive income are similar, despite being presented in various forms.

This article aims to identify changes in the form of the statement of comprehensive income in companies in the WIG30 (the Warsaw Stock Exchange Index comprises the 30 largest joint-stock companies in Poland) and the DAX (Deutscher Aktienindex is the main German stock index. It comprises the 30 largest joint-stock companies) indices. It also aims to identify and grade components of other comprehensive income in terms of the information transparency of the presentation options. The article also includes the effect of national cultural dimensions on the form of the statement of comprehensive income.

The study identified four options for the presentation of other comprehensive income components used by the surveyed companies in 2012-2014. It seems that the particular option chosen for the presentation of the items of other comprehensive income may reflect the varied information transparency of the statement of comprehensive income. It should be noted that according to the efficient market theory the form of presentation of comprehensive income is not important, because it does not affect the investors' decisions, as they have all known information (Turktas, Georgakopoulos, Sotiropoulos \& Vasileiou, 2013 p. 1; Rees \& Shane, 2012, p. 807). At the same time Hirst and Hopkins (1998, p. 49) and Maines and McDaniel (2000, pp. 180-182) suggest that the form of presentation of components of comprehensive income can affect how investors interpret information. This view is shared by Bamber, Jiang, Petroni and Wang (2010, p. 99), who noticed, that if investors only focus on the bottom line items and the statement of comprehensive income is drawn up together with the profit and loss account, it is possible that they overemphasize the components 
of other comprehensive income. Therefore, because the components of other comprehensive income are generally volatile and transitory, it may make investors think that performance of the company is more volatile. It seems, therefore, that research concerning the form of the statement of comprehensive income is justified.

The content presented in this article was prepared based on literature studies and an analysis of 180 consolidated financial statements from public companies. The inductive reasoning was used in the article. The research process involved descriptive statistics, and the structural similarity index. The structure of this paper is as follows. The first section presents considerations on the lack of information transparency of modern financial statements. The second section indicates the guidelines of IAS 1 on the presentation of components of other comprehensive income. The third section presents the results of research on comprehensive income conducted by research centres around the world. The fourth section contains the results of empirical research conducted by the author on the presentation of the components of other comprehensive income by public companies in Poland and Germany.

\section{LITERATURE REVIEW}

\section{Transparency of financial statements in the presence of an excess of information in the reports of companies}

As shown by research results, an increase in the amount of information contained in the financial statements does not always increase their usefulness (International Accounting Standards Board [IASB], 2013). Increasingly, it has been suggested that, rather than increasing the amount of information, it should be reduced, simplified. It is extremely difficult to find a happy medium in this area. These are the dilemmas which face company management and organizations developing reporting standards.

The length of financial statements increases from year to year. This is confirmed by the results of research conducted by Deloitte among the companies listed on the London Stock Exchange (Deloitte, 2010). As noted by Vos (2013a, p. 24), too long financial statements are less effective as a communication tool between a company and its environment. Users are not able to understand the essence of the economic situation of the entity, because they are too involved in the quest for the essence. Too long financial statements confuse users, and information overload begins to obscure the relevant information (Vos, 2013a, p. 26; Vos, 2013b, p. 55).

Another problem concerns the form of presentation of information in financial statements. The results of a survey conducted in 2012 among members 
of the Chartered Financial Analyst Institute (the CFA Institute) indicate that "investors believe improved financial statement presentation is a key element to improving financial reporting because poor financial statement presentation limits transparency" (CFA Institute, 2013, p. 18). A survey implemented by the CFA Institute $(2013$, p. 6$)$ found that as many as $82 \%$ of investors indicated that the priority changes in financial reporting should include an improvement to the presentation of information in financial statements, including improvement in the consistency of the information contained therein.

The problem of a lack of information transparency in financial statements, to the greatest extent, relates to the notes. The Financial Accounting Standards Board (FASB) and the European Financial Reporting Advisory Group (EFRAG) are currently making efforts to create an overriding conceptual disclosure framework, which is aimed at making disclosures more organized. Disclosures should also contain less unnecessary information. It should be noted, however, that these efforts are not entirely consistent with the expectations of investors. The study conducted by the CFA Institute $(2013$, p. 7$)$ found that as many as $85 \%$ of investors indicated that before a disclosure framework concerning information in the notes has been prepared, standards' setters should once again examine what information is now presented in the financial statements.

According to P. Lee, from the perspective of users, more information is not necessarily better, just as less information is not necessarily better, instead, better quality information is needed (IASB, 2013, p. 6). This view is shared by Walińska (2009, p. 164), according to whom the real challenge today is not to increase the amount of disclosures, but to provide relevant and useful information, and present it in an intelligible form.

It seems that, especially from the point of view of utility of the statement of comprehensive income, the proper form of presentation of information is crucial, because the form may be determined not only by the regulations but may also depend on cultural values of the country. The literature indicates that the differences between the models of accounting are caused by cultural values which affect the institutional structure of particular countries (Doupnik \& Salter, 1995; Lawrence, 1996).

\section{Presentation of information on other comprehensive income under IAS 1}

The presentation of comprehensive income is associated with the use of a valuation model which applies "clean surplus accounting." The approach of clean surplus accounting is related to the fact that the income statement reflects all changes in equity, excluding transactions with owners (Ohlson, 1995; Feltham \& Ohlson, 1995; Szychta, 2012). 
Comprehensive income comprises all components of the profit and loss account and other comprehensive income (International Accounting Standard 1 [IAS 1], 2008, paragraph 7).

The concept of comprehensive income was implemented to International Accounting Standards (IAS/IFRS) in 2008 (IAS 1, 2008). Since 2009, companies which prepare their financial statements in accordance with IAS/IFRS have been required to present comprehensive income. IAS 1 provides only general guidance as to the structure and content of the financial statements, including the statement presenting other comprehensive income.

As regards the method of presentation of items of other comprehensive income, the entities can choose from two options (IAS 1, 2008, paragraph 81):

- Option I-a single statement of profit or loss and other comprehensive income.

- Option II-two statements: a statement of profit or loss and a second statement, which shall begin with the net profit (loss) and present items of other comprehensive income.

Two forms of presenting the tax effects relating to other comprehensive income are also allowed. An entity may present items of other comprehensive income either net of related tax effects or before recognizing any tax effects (IAS 1, 2008, paragraph 91).

Reclassification adjustments are an important part of the statement of comprehensive income. They can be presented among items of other comprehensive income or in the notes. The principles of presenting other comprehensive income were amended in 2012 (IAS 1, 2012). Entities shall apply those amendments for annual periods beginning on or after 1 July 2012, and entities required to comply with IAS/IFRS must apply the provisions of the IAS 1 amended in 2012, which implies e.g. the breakdown of items of other comprehensive income into two sections (IAS 1, 2012). The first section relates to items that will not be reclassified to net profit (loss), while the second section presents the items that will be subsequently reclassified to net profit (loss) when specific conditions are met. IAS 1 does not provide guidance as to how each section presents items of other comprehensive income.

\section{Other comprehensive income as part of the financial statements: The main conclusions from global research}

Views on the usefulness of information contained in comprehensive income are varied. The main argument in favour of the limited usefulness of items of other comprehensive income is the fact that they are transitory in nature. They do not concern the basic activities and are limited in usefulness, 
in comparison with the net profit or loss, in forecasting cash flows of the company. It is also noted that items of other comprehensive income produce information noise, which makes the performance of an entity more difficult to predict (Black, 1993; Dhaliwal, Subramanyam \& Trezevant, 1999; Holthausen \& Watts, 2001; Barton, Hansen \& Pownall, 2010). Supporters of the presentation of other comprehensive income indicate that the net profit or loss together with other comprehensive income reflect all sources of value creation (Johnson, Reither \& Swieringa, 1995; Smith \& Reither, 1996). The introduction of comprehensive income was a response to the problem of creative accounting and lack of transparency (O'Hanlon, 2000, p. 1303). Companies shifted some of their revenues and expenses to equity in order to eliminate their impact on net profit or loss. In this way, companies could manipulate users of financial statements, since they were more focused on the financial result than on changes in the level of equity (Marcinkowska, 2003, p. 95; Bek-Gaik, 2013, p. 908). Comprehensive income can eliminate this problem.

The results of studies on the usefulness of disclosures on comprehensive income are not clear. According to Cheng, Cheung and Gopalakrishnan (1993, pp. 195-203), investors pay more attention to operating than non-operating items. Studies in the USA indicate that investors attach particular importance to the two components of other comprehensive income, i.e., to gains and losses arising from translating the financial statements of foreign operations and unimplemented gains and losses from investments in equity instruments measured at fair value through other comprehensive income (Chambers, Linsmeier, Shakespeare \& Sougiannis, 2007, pp. 557-593).

The results of studies carried out among European countries indicate that comprehensive income is value relevant, but less so than net profit or loss (Lin, 2006, pp. 1110-1141). Significantly, the results confirm that the format of the presentation of comprehensive income is important from the point of view of investors. At the same time, taking into account differentiated results of studies, it is difficult to identify clearly which form of presentation they prefer (Chambers et al., 2007, p. 559; Maines \& McDaniel, 2000, pp. 180-182; Hirst \& Hopkins, 1998, pp. 48-50).

Regarding the problem with the presentation of components of other comprehensive income within the income statement or as a separate statement, the studies indicate a failure to gain more information related to the reporting of comprehensive income in a separate statement (Chambers et al., 2007, pp. 559-560). As noted by Rees and Shane (2012, p. 809), there are no reliable research results in this area.

The issue of reclassification is crucial when considering comprehensive income. In accordance with IAS/IFRS, reclassification should not be made in 
the event of gains or losses arising from defined benefit plans and in the event of gains and losses from the revaluation of fixed assets and intangible assets (Rees \& Shane, 2012, p. 810). What is important is that users of information (both experts in the field of accounting, and others) pay more attention to items of comprehensive income which are not subject to reclassification. According to Tarca, Brown, Hancock, Woodliff, Bradbury and van Zijl (2008, pp. 184-217), this is due to the fact that reclassification introduced additional difficulties which complicate the process of obtaining information.

\section{RESEARCH METHODS}

The examined group comprised companies in the Polish WIG30 index and the German DAX index. Companies in the DAX index: ADIDAS, ALLIANZ, BASF, BAYER, BEIERSDORF, BMW, COMMERZBANK, CONTINENTAL, DAIMLER, DEUTSCHE BANK, DEUTSCHE BOERSE, DEUTSCHE POST, DEUTSCHE TELEKOM, E.ON, FRESENIUS MEDI, FRESENIUS, HEILDELBERG CEMENT, HENKEL, INFINEON TECH, K+S, LANXESS, LINDE, LUFTHANSA, MERCK KGAA, MUNICH RE, RWE, SAP, SIMENS, THYSSENKRUPP, VOLKSWAGEN. Companies in the WIG 30 index: ALIOR, ASSECO, BORYSZEW, BZ WBK, CCC, CITI HANDLOWY, CYFROWY POLSAT, ENEA, EUROCASH, GRUPA AZOTY, GTC, ING BANK ŚLĄSKI, JSW, KERNEL, KGHM, LOTOS, LPP, BOGDANKA, MBANK, NETIA, ORANGE, ORLEN, PGE, PGNIG, PKO BP, PKO SA, PZU, SYNTHOS, TAURON, TVN. One hundred and eighty consolidated financial statements for the years 20122014 were examined.

These entities were selected because of the similar number of companies in the WIG30 index and the DAX index, which facilitated comparability. Since 2009, companies operating both on the Polish and German capital markets have been obliged to present other comprehensive income. This fact facilitated an analysis of the changes in reporting practice in this area. The companies in the WIG30 were chosen for the study due to the fact that the Warsaw Stock Exchange is the largest stock exchange in those countries which are "new" Member States of the European Union. In turn, companies in the German DAX index were chosen for the study due to the fact that the German economy is the strongest in the European Union. It seems, therefore, that the companies in the DAX index are an appropriate benchmark for comparative research. Importantly, the examined entities operate in the same continental accounting model.

The companies surveyed represented nine sectors among which Heavy Industry, Finance, and IT and Telecommunications were predominant (see Table 1). 
Table 1. Breakdown by sectors of the WIG 30 and DAX companies

\begin{tabular}{llll}
\hline $\mathbf{N}$. & Sector & WIG $\mathbf{3 0}(\%)$ & DAX (\%) \\
\hline 1. & Heavy industry & 40.0 & 36.7 \\
2. & Finance & 26.7 & 13.3 \\
3. & IT and Telecommunication & 10.0 & 13.3 \\
4. & Trade & 10.0 & 3,3 \\
5. & Media & 6.7 & 0.0 \\
6. & Light industry & 3.3 & 20.0 \\
7. & Construction & 3.3 & 3.3 \\
8. & Services & 0.0 & 6.7 \\
9. & Capital market & 0.0 & 3.3 \\
\hline
\end{tabular}

The study has determined how the form of the statement of comprehensive income among companies in the WIG30 and DAX indices changed in the period. It was crucial to determine how the change in the form of the statement of comprehensive income affected the information transparency of this statement. It should be noted that the transparency of information is a subjective concept, in this article it has been evaluated by the Author. The results indicate that the average share of other comprehensive income in the net profit (loss) increased in companies in both indices in the period. In addition, the share was much higher in the case of the DAX index (see Table 2).

For $75 \%$ of the surveyed companies in the WIG30, the average share of other comprehensive income in the net profit (loss) for the period was $22.2 \%$ or less in $2012,14.4 \%$ or less in 2013 and $20.2 \%$ or less in 2014 , while for $75 \%$ of the surveyed companies in the DAX index the share of other comprehensive income in the net profit (loss) stood at $60.9 \%$ or less in $2012,69.6 \%$ or less in 2013 and $98.6 \%$ or less in 2014 . In 2014, the standard deviation for companies in the WIG30 was $41.9 \%$, while in the case of the DAX it was as much as $84.2 \%$. This means that in 2014 the average share of other comprehensive income in the net profit (loss) was more varied in the case of the DAX index than in the case of companies in the WIG30.

Considering the average share of other comprehensive income in the net profit (loss), it can be concluded that for companies both in the WIG30 and the DAX indices other comprehensive income is a significant value. 
Table 2. Descriptive statistics on the average share of other comprehensive income in the net profit (loss) in the surveyed companies

\begin{tabular}{lrrrrrr}
\hline & \multicolumn{3}{c}{ WIG30 (\%) } & \multicolumn{3}{c}{ DAX (\%) } \\
\cline { 2 - 7 } & Year 2012 & Year 2013 & Year 2014 & Year 2012 & Year 2013 & Year 2014 \\
\hline Arithmetic average & 19.0 & 23.7 & 23.9 & $39.0 *$ & 62.3 & $78.5 * *$ \\
Median & 10.7 & 7.1 & 10.2 & 31.1 & 24.09 & 50.5 \\
Percentile 25 & 4.9 & 2.0 & 4.9 & 9.1 & 11.1 & 29.8 \\
Percentile 75 & 22.2 & 14.4 & 20.2 & 60.9 & 69.6 & 98.6 \\
Standard deviation & 22.1 & 53.9 & 41.9 & 38.6 & 89.2 & 84.2 \\
Minimum value & 0.0 & 0.0 & 0.1 & 0.5 & 0.4 & 1.7 \\
Maximum value & 106.1 & 222.2 & 199.5 & 1964.3 & 330.5 & 2602.7 \\
\hline
\end{tabular}

* While calculating the arithmetic mean and standard deviation, one extremely high value was omitted (this concerned COMMERZBANK, where the share of other comprehensive income in the net profit stood at $1964.3 \%)$.

** While calculating the arithmetic mean and standard deviation, one extremely high value was omitted (this concerned Lufthansa, where the share of other comprehensive income in the net profit stood at $2602.7 \%)$.

The study also determined the average share of other comprehensive income in total assets. In the case of both indices, the average share was not more than $2.0 \%$ (see Table 3). It seems, therefore, that in terms of the average share of other comprehensive income in total assets, it is not a significant item. The average share of comprehensive income in total assets is declining from year to year for the DAX companies. On the other hand, in the case of companies in the WIG30 index, the average share decreased in 2013, but increased significantly in 2014.

Table 3. Descriptive statistics on the value of the average share of other comprehensive income in total assets of the surveyed companies

\begin{tabular}{lccccccc}
\hline & \multicolumn{3}{c}{ WIG30 (\%) } & \multicolumn{3}{c}{ DAX (\%) } \\
\cline { 2 - 7 } & Year 2012 & Year 2013 & Year 2014 & Year 2012 & Year 2013 & Year 2014 \\
\hline Arithmetic average & 0.7 & 0.3 & 1.3 & 1.9 & 1.4 & 2.0 \\
Median & 0.4 & 0.2 & 0.4 & 1.0 & 1.0 & 1.8 \\
Percentile 25 & 0.2 & 0.1 & 0.1 & 0.2 & 0.3 & 0.9 \\
Percentile 75 & 1.0 & 0.4 & 1.3 & 1.9 & 2.0 & 2.8 \\
Standard deviation & 0.8 & 0.4 & 2.3 & 3.6 & 1.4 & 1.5 \\
Minimum value & 0.0 & 0.0 & 0.0 & 0.0 & 0.0 & 0.0 \\
Maximum value & 3.4 & 1.5 & 11.2 & 20.4 & 6.6 & 6.4 \\
\hline
\end{tabular}


In 2014, for $75 \%$ of companies in the DAX index, the average share of other comprehensive income in total assets was $2.8 \%$ or less, while in the same year for $75 \%$ of the surveyed companies in the WIG30, the average share of other comprehensive income in total assets was $1.3 \%$ or less. The results confirm the high volatility of other comprehensive income.

\section{ANALYSIS AND STUDY}

In the first place, the study established the general form of the statement of comprehensive income. Over the period, companies in the DAX index presented the components of other comprehensive income in two statements, with most companies in the WIG30 index also using this form of presentation. At the same time, 40\% of companies from this index in 2012 and $36.7 \%$ in the period from 2013 to 2014 presented comprehensive income within a single statement.

Over $80 \%$ of the DAX companies presented profit and loss account and the statement of other comprehensive income in two separate pages of the annual report. In addition, every year the share of companies opting for this form of presentation increases. A similar tendency can be observed also among companies in the WIG30 index. This share, however, is significantly lower in comparison to the DAX index companies. This is because some WIG30 companies present the profit and loss account and statement of other comprehensive income in one report (see Table. 4).

Table 4. The general form of presentation of the statement of comprehensive income used by the WIG30 and DAX companies

\begin{tabular}{|c|c|c|c|c|c|c|}
\hline & \multicolumn{3}{|c|}{ WIG 30 (\%) } & \multicolumn{3}{|c|}{ DAX (\%) } \\
\hline & $\begin{array}{l}\text { Year } \\
2012\end{array}$ & $\begin{array}{l}\text { Year } \\
2013\end{array}$ & $\begin{array}{l}\text { Year } \\
2014\end{array}$ & $\begin{array}{l}\text { Year } \\
2012\end{array}$ & $\begin{array}{l}\text { Year } \\
2013\end{array}$ & $\begin{array}{l}\text { Year } \\
2014\end{array}$ \\
\hline $\begin{array}{l}\text { Presentation of the profit and loss account } \\
\text { and statement of comprehensive income in } \\
\text { one statement }\end{array}$ & 40.0 & 36.7 & 36.7 & 0.0 & 0.0 & 0.0 \\
\hline $\begin{array}{l}\text { Presentation of the profit and loss account } \\
\text { and statement of comprehensive income in } \\
\text { two statements }\end{array}$ & 60.0 & 63.3 & 63.3 & 100 & 100 & 100 \\
\hline $\begin{array}{l}\text { Presentation of the profit and loss account } \\
\text { and statement of comprehensive income on } \\
\text { one page in the annual report }\end{array}$ & 53.3 & 46.7 & 43.3 & 16.7 & 13.3 & 10.0 \\
\hline $\begin{array}{l}\text { Presentation of the profit and loss account } \\
\text { and statement of comprehensive income on } \\
\text { two pages in the annual report }\end{array}$ & 46.7 & 53.3 & 56.7 & 83.3 & 86.7 & 90.0 \\
\hline
\end{tabular}

The results show that to a large extent the presentation of the profit and loss account and the statement of other comprehensive income on one 
or two pages of the annual report coincides with their presentation within one or two statements. In 2012, one company, and in 2013 and 2014, two WIG30 companies presented the profit and loss account and statement of other comprehensive income on two pages of the annual report, even though they were drawn up within a single statement. On the other hand, in the years 2012-2013 five WIG30 companies, and in 2014 four WIG30 companies presented the profit and loss account and the statement of other comprehensive income on one page of the annual report, although these were separate statements.

Most companies within both indices presented deferred tax in the statement of comprehensive income (see Table 5). This form of presentation seems to be beneficial for users of the financial statements, as they do not have to look for that information in the notes. In most cases, the investigated companies presented the total amount of deferred tax on all components of other comprehensive income in the statement of comprehensive income. Selected companies presented the deferred tax for each component of other comprehensive income, while other companies of the DAX index presented the gross amount, the net amount and the deferred tax for each component of other comprehensive income.

Table 5. Percentage share of companies within the WIG30 and the DAX indices presenting deferred tax in the statement of comprehensive income

\begin{tabular}{lllllll}
\hline & \multicolumn{3}{c}{ WIG30 companies (\%) } & \multicolumn{3}{c}{ DAX companies (\%) } \\
\cline { 2 - 7 } & Year & Year & Year & Year & Year & Year \\
& $\mathbf{2 0 1 2}$ & $\mathbf{2 0 1 3}$ & $\mathbf{2 0 1 4}$ & $\mathbf{2 0 1 2}$ & $\mathbf{2 0 1 3}$ & $\mathbf{2 0 1 4}$ \\
\hline $\begin{array}{l}\text { Presentation of deferred income tax in } \\
\text { the statement of comprehensive income }\end{array}$ & 66.7 & 73.3 & 76.7 & 66.7 & 66.7 & 66.7 \\
\hline
\end{tabular}

The results show that companies in the DAX index presented more components of other comprehensive income. Some components of other comprehensive income were presented by all companies of the DAX index (e.g. Actuarial gains and losses on defined benefit plans in the years from 2013 to 2014).

The companies in the WIG30 and DAX indices most often presented the item Gains and losses arising from translating the financial statements of foreign operations. The share of companies in the WIG30 index which did not present any notes on the components of other comprehensive income decreased over the period. In companies in the DAX index, this share declined over the years 2012-2013, then rose again in 2014 (see Table 6). In 2013 and 2014 , in the case of both indices, most companies presented the notes 
on the components of other comprehensive income. Moreover, for most companies (mainly in the DAX index), an increase in the number of notes was accompanied by more information in the statement of other comprehensive income.

It should be noted that in 2014, the share of companies presenting a certain number of notes was very similar in both indices (the structural similarity index was as high as 0.93).

Table 6. The percentage share of companies presenting a certain number of notes on the components of other comprehensive income

\begin{tabular}{lccccccc}
\hline & \multicolumn{3}{c}{ WIG30 (\%) } & \multicolumn{3}{c}{ DAX (\%) } \\
\hline Number of notes & Year 2012 & Year 2013 & Year 2014 & Year 2012 & Year 2013 & Year 2014 \\
\hline 0 & 50.0 & 43.3 & 43.3 & 50.0 & 33.3 & 40.0 \\
1 & 26.7 & 26.7 & 23.3 & 20.0 & 23.3 & 20.0 \\
2 & 20.0 & 13.3 & 13.3 & 13.3 & 23.3 & 13.3 \\
3 & 0.0 & 10.0 & 13.3 & 6.7 & 10.0 & 16.7 \\
4 & 0.0 & 3.3 & 3.3 & 6.7 & 3.3 & 3.3 \\
5 & 3.3 & 3.3 & 3.3 & 3.3 & 6.7 & 6.7 \\
\hline
\end{tabular}

Four options of presenting the components of other comprehensive income can be identified in the reporting practice of the examined companies, with individual options reflecting the different levels of information transparency. It seems that the higher the option, the higher the level of transparency (Option No 1 - low level of information transparency, Option No. 4 - high level of information transparency) (see Table 7).

Option No 1 involves the presentation of the components of other comprehensive income in one group (without distinguishing items subject or not subject to reclassification and without specifying the value of reclassification adjustments). Under Option No 2, the components of other comprehensive income were divided into two groups, the first of which presented the components of other comprehensive income subject to reclassification to profit or loss (without specifying the value of reclassification adjustments), while the second group presented items not subject to reclassification to profit or loss (Option 2A). One of the companies in the WIG30 index presented the components of other comprehensive income in one group, while pointing out the total value of components subject and not subject to reclassification (Option 2B). Under this option, reclassification adjustments should be presented in the notes. Under Option No 3, the companies presented the components of other comprehensive income in a single group. Among the components of other comprehensive 
income (subject to reclassification), companies presented the change in value of the components of other comprehensive income during the financial year (not recognized in the income statement) as well as reclassification adjustments. Option 4 is the resultant of Option No 2 and Option No 3. Under this option the components of other comprehensive income were divided into two groups, the first of which presented the components subject to reclassification to profit or loss, and the second, in turn, the components not subject to such reclassification. In the first group of individual components there was detailed information on the reclassification to net profit (loss) and changes in fair value not recognized in profit or loss for the period. It appears that option 4 provides full information on comprehensive income.

The concept of comprehensive income is fairly complex. A change in the value of a given component of other comprehensive income may result both from the valuation of this component, as well as from the reclassification to profit or loss of the current period. In a situation where an entity does not present reclassification adjustments in the statement of comprehensive income, it should disclose this information in the notes. The practice of reporting indicates, however, that companies do not disclose this information in the notes either, with a number of the surveyed companies not drawing up notes concerning other comprehensive income. Therefore, if the companies do not present reclassification adjustments (in the statement of comprehensive income or in the notes), the users of financial statements do not have full information on the comprehensive income. The form of presentation and the resulting transparency of the statement of comprehensive income are of fundamental importance in terms of its usefulness.

The results show that, despite companies of the two indices applying the same regulations, the form of presenting the components of other comprehensive income varied and changed over the period. In 2012, among companies in the WIG30 index, as many as $83.3 \%$ chose Option No 1 , while in the same year, only $46.7 \%$ of the DAX companies chose this option. At the same time, $43.3 \%$ of the companies in the DAX index presented the items of other comprehensive income under Option No 3, and thus disclosed reclassification adjustments in the statement of comprehensive income. The year 2013 was crucial in terms of the presentation of the items of other comprehensive income. Since 1 January 2013, companies have been required to present the components of other comprehensive income in two groups, i.e. items subject or not subject to reclassification to net profit (loss) (see Table 8). 
Table 7. Four options for presenting the components of other comprehensive income by the examined companies in the WIG30 and DAX

\begin{tabular}{|c|c|}
\hline $\begin{array}{l}\text { Options of } \\
\text { presentation }\end{array}$ & Items of other comprehensive income \\
\hline Option 1 & $\begin{array}{l}\text { Item of other comprehensive income } \\
\text { Item of other comprehensive income } \\
\text { Deferred taxes }\end{array}$ \\
\hline Option 2 & $\begin{array}{l}\text { Items of other comprehensive income that will be reclassified subsequently } \\
\text { to profit or loss } \\
\text { Item of other comprehensive income } \\
\text { Item of other comprehensive income } \\
\text { Deferred taxes } \\
\text { Items of other comprehensive income that will not be reclassified } \\
\text { subsequently to profit or loss } \\
\text { Item of other comprehensive income } \\
\text { Item of other comprehensive income } \\
\text { Deferred taxes }\end{array}$ \\
\hline B & $\begin{array}{l}\text { Item of other comprehensive income } \\
\text { Item of other comprehensive income } \\
\text { including: } \\
\text { Value of items of other comprehensive income that will be reclassified } \\
\text { subsequently to profit or loss } \\
\text { Value of items of other comprehensive income that will not be reclassified } \\
\text { subsequently to profit or loss }\end{array}$ \\
\hline Option 3 & $\begin{array}{l}\text { Item of other comprehensive income } \\
\text { Reclassifications to net income } \\
\text { Changes arising during the year } \\
\text { Deferred taxes } \\
\text { Item of other comprehensive income } \\
\text { Reclassifications to net income } \\
\text { Changes arising during the year } \\
\text { Deferred taxes }\end{array}$ \\
\hline Option 4 & $\begin{array}{l}\text { Items of other comprehensive income that will be reclassified subsequently } \\
\text { to profit or loss } \\
\text { Item of other comprehensive income } \\
\text { Reclassification to net income } \\
\text { Change in value not recognised in income statement } \\
\text { Item of other comprehensive income } \\
\text { Reclassification to net income } \\
\text { Change in value not recognised in income statement } \\
\text { Income taxes relating to components of other comprehensive income* } \\
\text { Items of other comprehensive income that will not be reclassified } \\
\text { subsequently to profit or loss } \\
\text { Item of other comprehensive income } \\
\text { Item of other comprehensive income } \\
\text { Income taxes relating to components of other comprehensive income }\end{array}$ \\
\hline
\end{tabular}

It should be noted that in $2013,10 \%$ of companies in the WIG30 index and $6.7 \%$ of the DAX index companies did not comply with the provisions of the amended IAS 1. In 2013, as many as $90 \%$ of companies in the WIG30, 
chose Option No 2, i.e. they divided the items of comprehensive income into two groups in their statements, i.e. items that are subject or not subject to reclassification. The same option was applied by $46.7 \%$ of the DAX companies. What is also important is the fact that up to $46.6 \%$ of companies in the DAX index went a step further in the process of improving the statement of comprehensive income. These companies presented the items of other comprehensive income under Option No 4, i.e. not only dividing the items of comprehensive income into two groups, but also presenting reclassification adjustments. In this context, one can say that the practice of reporting used in 2013 by companies in the DAX was characterized by greater transparency.

In 2014, the share of companies which presented the items of other comprehensive income under Option No 1 decreased in both indices, and stood at 3.3\% among companies in the WIG30 and $6.7 \%$ among companies in the DAX index. Almost all companies (96.7\%) in the WIG30 presented the items of other comprehensive income under Option No 2. In the case of the DAX index, the items of other comprehensive income were presented under Option No 2 by $40 \%$ of companies, while over $50 \%$ of the DAX companies presented the items of other comprehensive income under Option No 4.

Treating consecutive options of the presentation of items of other comprehensive income as stages of the development of reporting in the area of comprehensive income, it can be concluded that the practice of reporting companies in the DAX index is ahead of the practice of reporting companies in the WIG30.

Table 8. The percentage share of companies in the WIG30 and the DAX presenting items of other comprehensive income in accordance with one of the four options

\begin{tabular}{lccccccc}
\hline \multicolumn{7}{c}{ WIG30 (\%) } & \multicolumn{7}{c}{ DAX (\%) } \\
\hline $\begin{array}{l}\text { Options of } \\
\text { presentation }\end{array}$ & Year 2012 & Year 2013 & Year 2014 & Year 2012 & Year 2013 & Year 2014 \\
\hline Option 1 & 83.3 & 10.0 & 3.3 & 46.7 & 6.7 & 6.7 \\
& Option 2A & 16.7 & 90.0 & 93.4 & 10.0 & 46.7 & 40.0 \\
Option 2 & Option 2B & 0.0 & 0.0 & 3.3 & 0.0 & 0.0 & 0.0 \\
\multirow{2}{*}{ Option 3 } & 0.0 & 0.0 & 0.0 & 43.3 & 0.0 & 0.0 \\
Option 4 & 0.0 & 0.0 & 0.0 & 0.0 & 46.6 & 53.3 \\
\hline
\end{tabular}

The difference in the form of presenting the statement of comprehensive income by companies in both indices increased in the period. This was confirmed by the increasingly lower value of the structural similarity index. In 2012 the index stood at 0.56, while in 2014 at 0.43 (see Table 9). It should be 
noted that in all years the index was at a level of 0.4 to 0.6 , which means that the structures are fairly similar.

Table 9. Structural similarity index in the years 2012-2014

\begin{tabular}{ccc}
\hline \multicolumn{3}{c}{ Structural similarity index value } \\
\hline Year 2012 & Year 2013 & Year 2014 \\
\hline 0.57 & 0.53 & 0.43 \\
\hline
\end{tabular}

The study sought to determine the impact of the sector in which individual companies operate, on the presentation of information on other comprehensive income. Three sectors were identified; those companies whose share in both indices was at least $10 \%$. In the case of the WIG30 significant differences were not identified in the presentation of components of other comprehensive income in individual sectors. In 2012 option No. 1 prevailed, while in the years 2013-2014 option No. 2. Differences concerning the presentation of components of other comprehensive income depending on the sector are visible in turn in the DAX companies. In 2014, all Finance DAX companies presented the components of other comprehensive income under Option 4 (the highest degree of transparency). In the same year, 63.6\% of companies from the Heavy Industry sector and $25 \%$ of companies from the IT and Telecommunication sector of the DAX index presented components of the other comprehensive income under Option 4 (see Table 10). The results indicate that in the case of the DAX companies there are significant differences regarding the presentation of the components of the other comprehensive income between the sectors.

The differences regarding the presentation of other comprehensive income by the DAX and WIG30 companies identified in the study may result from cultural differences. National cultural dimensions were the subject of research conducted by Hofstede and Hofstede (2007). They identified the following national cultural dimensions: large vs. small power distance; collectivism vs. individualism; masculinity vs. femininity; strong vs. weak uncertainty avoidance; long- vs. short-term orientation. According to the Author, taking into account the scope of optional disclosures, the dimension of national cultures concerning the avoidance of uncertainty seems to be particularly important. 
Table 10. The percentage share of companies in the WIG30 and the DAX presenting items of other comprehensive income in accordance with one of the four options - by sectors

\begin{tabular}{|c|c|c|c|c|c|c|}
\hline \multirow[b]{2}{*}{$\begin{array}{l}\text { Options of } \\
\text { presentation }\end{array}$} & \multicolumn{3}{|c|}{ WIG30 (\%) } & \multicolumn{3}{|c|}{$\operatorname{DAX}(\%)$} \\
\hline & Year 2012 & Year 2013 & Year 2014 & Year 2012 & Year 2013 & Year 2014 \\
\hline \multicolumn{7}{|c|}{ Heavy Industry } \\
\hline Option 1 & 75.0 & 0.0 & 0.0 & 54.5 & 0.0 & 0.0 \\
\hline Option 2 & 25.0 & 100.0 & 100.0 & 9.1 & 54.5 & 36.4 \\
\hline Option 3 & 0.0 & 0.0 & 0.0 & 36.4 & 0.0 & 0.0 \\
\hline Option 4 & 0.0 & 0.0 & 0.0 & 0.0 & 45.5 & 63.6 \\
\hline \multicolumn{7}{|c|}{ IT \& Telecommunication } \\
\hline Option 1 & 66.7 & 0.0 & 0.0 & 25.0 & 0.0 & 0.0 \\
\hline Option 2 & 33.3 & 100.0 & 100.0 & 50.0 & 75.0 & 75.0 \\
\hline Option 3 & 0.0 & 0.0 & 0.0 & 25.0 & 0.0 & 0.0 \\
\hline Option 4 & 0.0 & 0.0 & 0.0 & 0.0 & 25.0 & 25.0 \\
\hline \multicolumn{7}{|c|}{ Finance } \\
\hline Option 1 & 100.0 & 12.5 & 0.0 & 0.0 & 0.0 & 0.0 \\
\hline Option 2 & 0.0 & 87.5 & 100.0 & 0.0 & 0.0 & 0.0 \\
\hline Option 3 & 0.0 & 0.0 & 0.0 & 100.0 & 0.0 & 0.0 \\
\hline Option 4 & 0.0 & 0.0 & 0.0 & 0.0 & 100.0 & 100.0 \\
\hline
\end{tabular}

Poland is one of the countries with a high level of uncertainty avoidance index. Of the 74 surveyed countries, Poland ranked 9 th in terms of uncertainty avoidance index. On the other hand Germany belongs to a group of countries with a moderate uncertainty avoidance index. Among 74 countries surveyed Germany ranked 43rd (Hofstede \& Hofstede, 2007, p. 182). Uncertainty avoidance is defined as the level of threat perceived by members of the given culture in the face of a new, unknown or uncertain situation (Hofstede \& Hofstede, 2007, p. 181). In countries with a low level of uncertainty avoidance index there is a higher level of innovation, while in countries with a high uncertainty avoidance index there is a higher accuracy of executing activities and a stronger need for their formalization. In countries with a high uncertainty avoidance index there is a need to cover everything in the provisions of law (Hofstede \& Hofstede, 2007, p. 357). It seems that the level of uncertainty avoidance index is reflected in the disclosures presented by companies, the scope of which is not precisely defined in the provisions of law or good practices. To a certain extent the disclosures on the components of comprehensive income have such character. Entities operating in a country with a high uncertainty avoidance index (e.g., Poland) will choose 
not to present detailed, non-compulsory disclosures. For countries with an average uncertainty avoidance index (Germany), the propensity to present optional disclosures will be higher. A higher level of transparency of the DAX companies, compared with the WIG 30 companies, was also confirmed in studies on the presentation of information in the management reports (Gad, 2016).

\section{CONCLUSION}

A key principle of the concept of comprehensive income is to increase the transparency of financial reporting. Components of other comprehensive income include capital gains and losses which, before the introduction of the concept of comprehensive income, were recognized only in equity items. According to the concept of comprehensive income, capital gains or losses of subsequent periods are presented beneath the current period's profit or loss.

It seems that an appropriate presentation is crucial in terms of understanding the concept of comprehensive income by users of financial statements. The lack of information on reclassification adjustments, or the disclosure of fragmentary information on this subject in accounting notes, may adversely affect the usefulness of the statement of comprehensive income.

The simultaneous implementation of the concept of comprehensive income in EU countries was an excellent opportunity to analyse the development of reporting practice in this area. During the period under study, all companies in the DAX index presented the components of other comprehensive income in two statements. In the case of companies in the WIG30, most (60-63\%) also used this form of presentation. This form of presentation allows for a clear separation of revenues and costs of the current period from gains and losses.

Four options of the presentation of components of other comprehensive income were identified over the years 2012-2014. Under Option No 1, components of other comprehensive income were presented in one group, without distinguishing items subject or not subject to reclassification and without specifying the value of reclassification adjustments. Under Option No 2 , components of other comprehensive income were divided into those items subject or not subject to reclassification (without indicating reclassification adjustments). Under Option No 3 (used by companies in the DAX index in 2012), components of other comprehensive income were not divided into those items subject or not subject to reclassification, and for each component of other comprehensive income (subject to reclassification), presented the value of reclassification adjustments. Option No 4 uses the division into 
components subject or not subject to reclassification, as well as presenting the value of reclassification adjustments. Option No. 4, used by companies in the DAX index, reflects the highest level of information transparency. Despite the fact that the companies of the two indices were applying the same regulations, they presented components of other comprehensive income under different options. The study determined that the dynamics of change in financial reporting in the area of the presentation of components of other comprehensive income was higher in the case of companies in the DAX index. The reporting practice exhibited by some companies in the DAX index may be regarded as exemplary.

The results of research on forms of presentation of components of other comprehensive income by the WIG30 and DAX companies correspond to one of the national cultural dimensions identified by Hofstede and Hofstede (2007). Poland belongs to a group of countries with a high uncertainty avoidance index. This is manifested, among others, by the fact that companies avoid optional disclosures, not regulated by provisions of law. On the other hand, Germany is one of the countries with a moderate uncertainty avoidance index. The DAX companies present in their statements of other comprehensive income the information which is not required by IAS 1, and which according to the Author, increases the usefulness of this statement.

The article complements the existing knowledge on forms of presentation of the statement of other comprehensive income in the practice of Polish and German companies. The research presented in this article is a reference point for further research involving a larger number of companies. In addition, a comparative study of an international nature would make it possible to identify the impact of cultural values on the practice of reporting. Promotion of the research findings presented in this article may contribute to an improvement in the practice of reporting on the components of comprehensive income.

\section{References}

Bamber, L., Jiang, J., Petroni, K., \& Wang, I. (2010). Comprehensive income: Who's afraid of performance reporting? The Accounting Review, 85(1), 97-126.

Barton, J., Hansen, T. B., \& Pownall, G. (2010). Which performance measures do investors around the world value the most - and why. The Accounting Review, 85(3), 753-789.

Bek-Gaik, B. (2013). Rachunek zysków i strat-Czas na zmiany? In A. Karmańska (Ed.), Nauka o Rachunkowości na Progu Gospodarki Opartej na Wiedzy (pp. 907-922). Warsaw, Poland: Szkoła Główna Handlowa w Warszawie. Black, F. (1993). Choosing Accounting Rules. Accounting Horizons, 7(4), 1-17. 
Chambers, D., Linsmeier, T. J., Shakespeare, C., \& Sougiannis, T. (2007). An Evaluation of SFAS No. 130 Comprehensive Income Disclosures. Review of Accounting Studies, 12, 557-593.

Chartered Financial Analyst Institute. (2013). Financial Reporting Disclosures: Investor Perspectives on Transparency. Trust. and Volume. Condensed Report. Retrieved from https://www.cfainstitute.org/ethics/Documents/ investor-perspectives-on-disclosures.pdf

Cheng, A., Cheung, J., \& Gopalakrishnan, V. (1993). On the Usefulness of Operating Income. Net Income and Comprehensive Income on Explaining Security Returns. Accounting and Business Research, 23(91), 195-203.

Deloitte. (2010). Drowning by Numbers. Surveying Financial Statements in Annual Reports. Retrieved from http://www.iasplus.com/en-gb/ publications/uk/other/drowning-by-numbers-2014-surveying-financialstatements-in-annual-reports/at_download/file/Drowning\%20by\%20 numbers.pdf

Dhaliwal, D., Subramanyam, K. R., \& Trezevant, R. (1999). Is comprehensive income superior to net income as a measure of firm performance? Journal of Accounting and Economics, 26(1-3), 43-67.

Doupnik, T., \& Salter, S. (1995). External environment, culture and accounting practice: A preliminary test of a general model of international accounting development. The International Journal of Accounting, 30(3), 189-202.

Feltham, J., \& Ohlson, J. A. (1995). Valuation and clean surplus accounting for operating and financial activities. Contemporary Accounting Research, 11(2), 689-731.

Gad, J. (2016). The pillars of internal control and risk management systems in relation to financial reporting: The perspective of the Polish and German capital markets. Zeszyty Teoretyczne Rachunkowości, 88(144), 37-60.

Hirst, D. E., \& Hopkins, P. E. (1998). Comprehensive income reporting and analysts' valuation judgments. Journal of Accounting Research, 36(3), 47-75.

Hofstede, G., \& Hofstede. G. J. (2007). Kultury i Organizacje. Warsaw, Poland: PWE.

Holthausen, R. W., \& Watts, R. L. (2001). The relevance of the value relevance literature for financial accounting setting. Journal of Accounting and Economics, 31(1-3), 3-75.

International Accounting Standard 1 Presentation of Financial Statements. (2008, December 17). Retrieved from http://eur-lex.europa.eu/legalcontent/EN/TXT/?uri=CELEX\%3A32008R1274

International Accounting Standard 1 Presentation of Financial Statements. (2012, June 5). Retrieved from https://publications.europa.eu/ en/publication-detail/-/publication/eccfbe52-781d-4b5e-9c5a13b25bdfb1bb/language-en

International Accounting Standards Board. (2013). Discussion Forum-Financial Reporting Disclosure Feedback Statement. Retrieved from http://www. ifrs.org/Alerts/PressRelease/Documents/2013/Feedback-StatementDiscussion-Forum-Financial-Reporting-Disclosure-May-2013.pdf 
Johnson, L., Reither, C., \& Swieringa, R. (1995). Toward reporting comprehensive income. Accounting Horizons, 9(4), 128-137.

Lawrence, S. (1996). International Accounting. London, England: International Thomson Business Press.

Lin, S. (2006). Testing the Information Set Perspective of UK Financial Reporting Standard No. 3: Reporting Financial Performance. Journal of Business. Finance and Auditing, 33, 1110-1141.

Maines, L. A., \& McDaniel, L. S. (2000). Effects of comprehensive income characteristics in nonprofessional investors' judgments: The role of financial statement presentation format. The Accounting Review, 75(2), 179-207.

Marcinkowska, M. (2003). Istota wyniku całościowego i jego ujmowanie w sprawozdawczości finansowej. Zeszyty Teoretyczne Rachunkowości, 17(33), 89-109.

O'Hanlon, J. (2000). Discussion of value relevance of mandated comprehensive income disclosures. Journal of Business Finance and Accounting, 27(9), 1303-1309.

Ohlson, J. A. (1995). Earnings, book values, and dividends in equity valuation. Contemporary Accounting Research, 11(2), 661-687.

Rees, L. L., \& Shane, P. B. (2012). Academic research and standard-setting: The case of other comprehensive income. Accounting Horizons, 26(4), 789-815.

Smith, P. A., \& Reither, C. L. (1996). Comprehensive income and the effect of reporting it. Financial Analysts Journal, 52(6), 14-19.

Szychta, A. (2012). Dochody całkowite w sprawozdaniach finansowych największych spółek notowanych na GPW w Warszawie. Folia Oeconomica, 263, 65-88.

Tarca, A., Brown, P., Hancock, P., Woodliff, D., Bradbury, M., \& van Zijl, T. (2008). Identifying decision useful information with the matrix format income statement. Journal of International Financial Management and Accounting, 19(2), 184-217.

Turktas, B., Georgakopoulos, G., Sotiropoulos, I., \& Vasileiou, K. Z. (2013). Reporting comprehensive income: Reasons for reporting choices and investor reactions. International Journal of Economics and Finance, 5(4), $1-20$.

Vos, P. (2013a). First step towards reduction of disclosure overload. MCA: Tijdschrift voor Financial Executives, 2, 24-30. Retrieved from http:// executivefinance.nl/wp-content/uploads/2015/02/MCA201302_031. pdf

Vos, P. (2013b). A first step towards reducing disclosure overload. Financial Management. Retrieved from http://www.fm-magazine.com/feature/ depth/first-step-towards-reducing-disclosure-overload

Walińska, E. (2009). Bilans jako Fundament Sprawozdawczości Finansowej w Kontekście Zmian Wspótczesnej Rachunkowości. Warsaw, Poland: Wolters Kluwer. 


\begin{abstract}
Polish)
Celem artykułu jest identyfikacja zmian formy sprawozdania z wyniku całościowego w spółkach należqcych do indeksów WIG 30 oraz DAX. Celem artykułu jest również identyfikacja oraz gradacja pod względem przejrzystości informacyjnej wariantów prezentacji składników pozostałego wyniku całościowego. W artykule uwzględniono również wpływ wymiarów kultur narodowych na formę sprawozdania z wyniku całościowego. W ramach badania ustalono, że większość badanych spółek prezentuje sprawozdanie z wyniku całościowego w ramach jednego sprawozdania. Na przestrzeni analizowanych lat zwiększyła się liczba not księgowych dotyczqcych wyniku całościowego prezentowanych przez spółki w sprawozdaniach finansowych. W procesie badawczym zidentyfikowano cztery warianty prezentacji składników pozostałego wyniku całościowego zastosowane przez badane spółki w latach 2012-2014. Poszczególne warianty odzwierciedlajq różnq przejrzystość informacyjnq sprawozdania z wyniku całościowego. Wyniki badań wskazujq, że praktyka sprawozdawcza w obszarze wyniku całościowego spółek z indeksu DAX wyprzedza praktykę sprawozdawczq spółek z indeksu WIG 30. Uzyskane wyniki badań dotyczqce przejrzystości informacyjnej sprawozdania z wyniku całościowego odpowiadajq jednemu z wymiarów kultur narodowych.
\end{abstract}

Keywords: sprawozdania finansowe, wynik całościowy, WIG 30, DAX, przejrzystość informacyjna.

\title{
Biographical note
}

Jacek Gad, Ph.D. is an assistant professor in the Department of Accounting, Faculty of Management, University of Lodz, Poland. His research interests focus on financial reporting, business reporting, corporate governance. Currently, he is conducting research in the area of the main features of the issuer's internal control and risk management systems in relation to the process of preparing financial statements. He is the author and co-author of about 50 publications in the field of accounting and corporate governance. 